\title{
Asfiksjofilia i kontrola. Nienormatywna praktyka w społeczno-kulturowej perspektywie
}

DOI: 10.19195/2083-7763.8.13

\section{Wstęp. Nota metodologiczna}

Niniejszy artykuł ma charakter opisowy i jest oparty na analizie wtórnej. Autor nie przeprowadził badań empirycznych, lecz skupił się na przeglądzie dostępnej literatury. Analiza materiału zastanego (desk research) dotyczy głównie wybranych źródeł anglojęzycznych. Powodem jest to, że w polskiej literaturze naukowej, jak wynikło z kwerendy, można odnaleźć niewiele publikacji prezentujących tę problematykę. Zagadnienie autodestrukcji w aktach seksualnych nie jest często podejmowane, co utrudnia określenie, w których krajach i z jaką częstotliwością występują te praktyki. Skutkuje to trudnościami w charakterystyce zjawiska w kontekście konkretnego społeczeństwa.

Asfiksja spleciona z erotyką jest obszarem trudno dostępnym dla badań. Wieloaspektowa niedostępność, choć stanowi poważne ograniczenie, stała się zarazem motywacją do poszukiwań. Zdaniem autora tego typu zachowania są z wielu względów ciekawym przedmiotem naukowej refleksji. Niektóre z tych powodów zostały przedstawione w artykule. Jego objętość ogranicza zakres eksploracji, zatem nie rości sobie prawa do wyczerpania tematu. Przedstawia problematykę, która dotychczas w Polsce (i nie tylko w tym kraju) nie cieszyła się zainteresowaniem socjologów. Koncentruje się przede wszystkim na faktograficznych aspektach zjawiska asfiksjofilii i jest pokłosiem wędrówki po materiałach filmowych, tekstach naukowych oraz opisywanych w nich zachowaniach, które okazały się bardzo intrygujące. Celem jest więc zwrócenie uwagi na praktykę, która z jednej strony funkcjonuje poza głównym nurtem kulturowym, z drugiej zaś jest ciekawą 
inspiracją dla interdyscyplinarnych rozważań. Wybrane wątki wpisują się w takie dyscypliny, jak socjologia, psychologia, neuropsychologia, psychoterapia, kryminalistyka itp., a powtarzającym się motywem są odniesienia do kontroli społecznej.

\section{Praktyki seksualne jako przedmiot kontroli społecznej}

Ludzkie zachowania są poddawane reglamentacji społecznej. Z jednej strony jesteśmy gatunkiem nadzwyczaj kreatywnym, na co pozwala pozbawiona sztywnych programów spuścizna ewolucyjna. $Z$ drugiej zaś innowacyjność jest kanalizowana przez instytucje społeczne, przywracające zachowaniom przewidywalność i pewność. Instytucje nie tyle tłumią twórczość, ile pozwalają jej rozwijać się na własnych warunkach. Możliwości zostają zawężone, oczekiwania zagęszczone i dopiero wtedy stają się głównym źródłem jednostkowych projektów, antycypacji oraz codziennych praktyk. Chociaż regulacja zachowań jest oparta przede wszystkim na głębokim uwewnętrznieniu uwzorowanych reakcji, których nośnikiem są instytucje, oraz na wzajemnym nadzorowaniu (każdy nakłania każdego do określonych stylów myślenia i działania; samokontrola jednostki względem innych wyznacza granice ich samokontroli) ${ }^{1}$, obowiązuje reguła ograniczonego zaufania. Doznania, emocje, poczucie słuszności czegoś i absurdalności czegoś innego, oczekiwania innych osób, na których szacunku i akceptacji komuś zależy, są bardzo ważne, ale nie zawsze wystarczające ${ }^{2}$. Dlatego też agenci formalnej kontroli społecznej stoją na straży obowiązujących reguł. Wszystko to razem sprawia, że większość naszych działań rozwija się w określonych kierunkach i powstają strefy, w których ciekawość jest wysoce niepożądana. Gratyfikacje i uznanie są dane tylko tym innowatorom, których działania mieszczą się w obrębie tego, co społecznie akceptowane.

Asfiksjofilia wpisuje się w obszar zachowań dewiacyjnych. Socjologiczne koncepcje dewiacji, w dużym uproszczeniu, lokują się między pytaniem o to, dlaczego ludzie naruszają normy, a zainteresowaniem, jak one są tworzone, egzekwowane i co dzieje się z osobami, które naznaczono piętnem dewiacyjnym (jak to wpływa na ich tożsamość oraz relacje z grupą i społeczeństwem). Innymi słowy, rozgrywają się między podejściem normatywnym a reaktywnym ${ }^{3}$. Jednakże położenie nacisku na normy społeczne i uczynienie z nich osi opisu asfiksjofilii nie doprowadzi raczej do ujawnienia nowych treści. Przeciwwagą normy (akceptowanego społecznie wzoru zachowania) jest dewiacja i sankcje jako ochronna reakcja na zagrożenia płynące z naruszenia porządku. Drugi rodzaj koncepcji akcentuje subiektywne interpretacje bodźców, możliwość rozwijania przez jednostkę odmiennych

${ }^{1}$ Por. M. Douglas, Jak myśla instytucje, przeł. O. Siara, Warszawa 2011, s. XVII-XXII; N. Elias, Społeczeństwo jednostek, przeł. J. Stawiński, Warszawa 2008, s. 36-80; J.-C. Kaufmann, Ego. Socjologia jednostki, przeł. K. Wakar, Warszawa 2004, s. 149-176.

${ }^{2}$ Por. H.S. Becker, Outsiderzy. Studia z socjologii dewiacji, przeł. O. Siara, Warszawa 2009, s. 63-83.

3 Zob. A. Siemaszko, Granice tolerancji. O teoriach zachowań dewiacyjnych, Warszawa 1993. 
linii działania, innowacyjnego wykorzystania jej społecznych doświadczeń, przy czym łatwo w nim zagubić ważną obserwację. Dotyczy ona tego, że jeśli jednostka ma być członkiem któregoś ze społecznych światów, nie może się zbytnio od niego oddalać. A to między innymi czyni bardzo realnym wywieranie wpływu przez instytucje społeczne, agendy formalnej kontroli społecznej, sankcje. Pozwala to też zrozumieć jednoczesne poszukiwanie nowych doświadczeń, wykorzystywanie w tym celu bardzo subiektywnych doznań i społecznych znaczeń oraz ukrywanie ich czy samotne przeprowadzanie. Dzieje się tak zwłaszcza gdy rezultaty tych połączeń przynoszą praktyki i konsekwencje mające transgresyjny potencjał, jakim są rozmaite zagrożenia wartości i zasad porządku zsocjalizowanych przez większość. To kwestie zarazem oczywiste, jak i ukrywające nakładające się przyczyny oraz linie podziałów w społeczeństwach tak mocno uznających na przykład rozdział na publiczne i prywatne czy indywidualne i społeczne. Podziały te mają znaczną moc regulacyjną i sprawują wiele funkcji. Jednakże indywidualne i prywatne (pozostawione $\mathrm{w}$ gestii wolnego wyboru jednostki i zarazem objęte dyskrecją, prawem do ukrycia przed opinią publiczną) wydaje się o wiele bardziej kruche i do odwołania. Seksualność zaś ostatnimi czasy zdaje się w tych względach bardzo dobrym obszarem do antropologiczno-socjologicznych studiów.

\section{Poza erotyką}

Mózg do sprawnego funkcjonowania potrzebuje określonego poziomu dotlenienia i błyskawicznie reaguje na spadek zawartości tlenu we krwi. Hipoksję charakteryzują zróżnicowane objawy: zakłócenia w funkcjonowaniu kognitywnym (zaburzenia pamięci, kłopoty z koncentracją, z podejmowaniem decyzji i umiejętnością prowadzenia kalkulacji matematycznych) i neurologicznym (upośledzenie koordynacji, drżenia, spazmy), pojawiają się: widzenie tunelowe, zanik kolorów i ostrości widzenia; może ona wywołać ból i zawroty głowy, uczucie zmęczenia i niepokoju, a także euforię i seksualnie zabarwioną ekscytację. Niedotlenienie wywołuje wiele odczuć dających szansę generowania indywidualnych interpretacji, dlatego ich doznawanie jako przykrych lub gratyfikujących jest subiektywne (a interpretacja tego samego bodźca potrafi być skrajnie odmienna w różnych momentach czy otoczeniach $)^{4}$. Wywołanie niedotlenienia nie musi być kojarzone z czynnościami seksualnymi i mieć na celu modyfikowania seksualnych wrażeń. Można je powiązać z różnymi kategoriami zachowań ludzkich. Anoksemia, czyli niedobór tlenu we krwi w stosunku do zapotrzebowania, jest zjawiskiem powszechnym u osób uprawiających dyscypliny sportowe nacechowane bardzo dużym wysiłkiem fizycznym. Po jego ekstremalnym natężeniu często dochodzi

\footnotetext{
${ }^{4}$ R.A. Westerman, Hypoxia familiarization training by the reduced oxygen breathing method aviation medicine, „ADF Health” 5, 2004.
} 
do omdleń. Spadek zawartości tlenu we krwi towarzyszy wspinaczom zdobywającym wielotysięczniki. Alpiniści opisują zazwyczaj przykre efekty tego zjawiska. Często uniemożliwia on osiągnięcie szczytu i/lub sukcesu sportowego. Technik podduszenia uczy się w judo i innych sportach walki. Policjanci są szkoleni w sposobach obezwładniania, a jednym $\mathrm{z}$ nich jest duszenie. Mistyczne eksploracje często są wspomagane technikami oddychania.

Dążenie do hipoksji niekiedy przyjmuje formę zabawy wpisanej w czas wolny. Tak jest w przypadku "gry w podduszenie” (choking game) ${ }^{5}$. Uczestnicy tego typu zabaw często doprowadzają siebie lub inne osoby do utraty świadomości. Gra zdaje się zyskiwać na popularności, czego odzwierciedleniem jest jej znacząca obecność na YouTube ${ }^{6}$. Młodzi ludzie, głównie adolescenci, zamieszczają i oglądają w Internecie filmiki obrazujące epizody podduszenia, dokonywane samodzielnie lub w towarzystwie ${ }^{7}$. W analizowanym materiale nie dopatrzono się kontekstu erotycznego. Celem było wywołanie niezwykłego stanu psychicznego spowodowanego niedotlenieniem mózgu. Zabawę zalicza się do niebezpiecznych, albowiem może prowadzić do uszkodzenia centralnego ośrodka nerwowego i w konsekwencji - śmierci ${ }^{8}$. Mogą również pojawić się urazy wynikające z niekontrolowanego upadku po utracie przytomności. Oprócz duszonego i duszącego w większości przypadków obecni są także inni uczestnicy/obserwatorzy. Są to więc zabawy zazwyczaj o społecznym charakterze. Pokłosiem tego są rzadsze przypadki śmierci niż w hipoksjach dokonywanych w pojedynkę.

Popularność YouTube wśród adolescentów (i nie tylko) powoduje, że zabawy tego rodzaju są łatwo propagowane i normalizowane. Część młodych ludzi chętnie eksperymentuje z choking game choćby dlatego, że jest to okazja, aby na chwilę bezpłatnie „odlecieć”. Internet z jednej strony rozpowszechnia informacje o tego typu zachowaniach i w pewnym sensie je propaguje, $z$ drugiej zaś powstają przekazy informacyjno-terapeutyczne, których celem jest ostrzeganie przed niebezpieczeństwem i sugerowanie skorzystania z pomocy osobom uwikłanym w tego typu proceder ${ }^{9}$. Rzeczywiście bowiem może on przyjąć formę uzależnienia. W jednym

${ }^{5}$ Zabawa w podduszenie jest bardzo różnie nazywana. Szukając filmików o tej tematyce na YouTube, badacze posługiwali się następującymi angielskimi terminami: Space Monkey, Flatliner, Breath Play, Space Cowboy, Funky Chicken, Suffocation Roulette, Passout, Tingling, California High, Rising Sun, Sleeperhold, American Dream, Airplaning, scarfing, terminal sex. Posłużyli się również hiszpańskim określeniem - Intento Desmayo. The fainting game, http://www.allaboutheaven.org/overload/40/107/the-fainting-game (dostęp: 3.09.2017).

611 Year Old Boy Dies While Playing „Choking Game”, https://www.youtube.com/watch?v=jljlunxLbQI (dostęp: 3.09.2017).

7 Proceder opisali między innymi kanadyjscy badacze - zob. M. Linkletter, K. Gordon, J. Dooley, The choking game and YouTube: A dangerous combination, „Clinical Pediatrics” 49, 2010, nr 3, s. 274279, https://www.ncbi.nlm.nih.gov/pmc/articles/PMC4839780/ (dostęp: 3.09.2017).

8 Wspomniane w poprzednim przypisie źródło powołuje się na osiemdziesiąt dwa przypadki śmierci adolescentów wywołane niedotlenieniem.

${ }^{9}$ G. A. S. P., games adolescent shouldn't play, http://www.gaspinfo.com/en/choking.html (dostęp: 3.09.2017). 
z raportów z badań znajduje się opis dwudziestopięcioletniego mężczyzny uzależnionego od wprowadzania się w stan hipoksji. Doprowadzał on niekiedy do czterdziestu tego typu epizodów w ciągu dnia. Obsesyjno-kompulsywny charakter zachowania niepowiązanego z seksualnością zakłócał rytm dnia codziennego i utrudniał nawiązywanie i podtrzymywanie relacji społecznych. Mężczyzna korzystał z pomocy psychologicznej mającej na celu kontrolowanie uzależnienia (podczas hospitalizacji został poddany terapii kognitywnej) ${ }^{10}$.

We wskazanych kontekstach hipoksja nie jest kojarzona $\mathrm{z}$ intensyfikacją doznań seksualnych, zdarza się asocjowanie z doznaniami podobnymi do narkotyzowania się. Patrząc z innej strony, trudno jednoznacznie oddzielić szczytowe doznania powiązane $\mathrm{z}$ ekstremalnym wysiłkiem i ryzykiem od euforii wynikającej $z$ deficytu życiodajnego tlenu. Można więc zaryzykować stwierdzenie, że manipulowanie poziomem tlenu odgrywa istotną rolę $\mathrm{w}$ generowaniu odmiennych stanów świadomości, z mistycznymi i religijnymi włącznie.

\section{Paradoks pierwszy: (auto)erotyczne i publiczne}

Społecznie uznawane praktyki seksualne pozostają w znacznej dysproporcji względem pomysłowości homo sapiens sapiens. Niektóre zachowania, choć stygmatyzowane i marginalizowane, są obecne społecznie i „scenicznie”. Na przykład kluby sadomasochistyczne lub swingerskie są miejscami przeformułowania obowiązujących zasad. Tego rodzaju enklawy wprowadzają na scenę i pozwalają obserwować (często współuczestniczącej widowni) akty traktowane $\mathrm{w}$ innych okolicznościach jako niemoralne i będące przejawami zaburzeń (parafilii). Istnieją także praktyki kategoryzowane jako autoerotyczne, gdyż rzadko wpisują się $\mathrm{w}$ interakcje międzyludzkie ${ }^{11}$. Samogwałt jest ich egzemplifikacją. Przeszedł w kulturze zachodniej przez zawiłości społecznych rekonstrukcji. Był ikoną patologii, dopatrywano się w nim przyczyn najpoważniejszych zaburzeń, moralnego zwyrodnienia, degrengolady i śmierci. Odium powoli ewaporowało. Paradygmat medyczny, uwikłany w wychowawczą propagandę, odegrał jedną z głównych ról w jego patologizacji i całkowitej depatologizacji ${ }^{12}$. Ipsacja jest współcześnie uważana przez seksuologów za normalne zachowanie (wpisane w seks zarówno solo, jak i partnerski, bywa wykorzystywana w terapii zaburzeń seksualnych); nadal

10 A. Ameller et al., Addiction to autoerotic asphyxia: A case-report, „Substance Abuse Alcohol” 4 (2), 2016, https://www.jscimedcentral.com/SubstanceAbuse/substanceabuse-4-1048.pdf.

11 To zachowanie jest przykładem trudności kategoryzacyjnych. Termin „autoerotyczne” wskazuje na czynność erotyczną dokonywaną na sobie samym. Jego ilustracją jest onanizm. Jednak partnerzy mogą także onanizować się nawzajem, czynność ta może również odbywać się w obrębie homo-, hetero- czy biseksualnej diady lub grupy, co powoduje, że nie mieści się już w obrębie autoerotyzmu.

12 Por. T.W. Laqueur, Samotny seks. Kulturowa historia masturbacji, przeł. M.P. Markowski, Kraków 2006. 
jest jednak figurą samotnego seksu. Figura ta usuwa z pola widzenia elementy z nią niezgodne, to znaczy okoliczności wzajemnej masturbacji, które nie rozrywają ram wspólnoty, a nawet są zdolne je tworzyć - tyle, że niekiedy w trudno akceptowany sposób. Istnieją wreszcie masturbacyjne modyfikacje (choć warto podkreślić, że omawiana $\mathrm{w}$ artykule praktyka może towarzyszyć innym formom seksualnym, ze stosunkami płciowymi włącznie), które na powrót czynią z niej, patrząc z perspektywy kontroli społecznej, czynność ekstremalną i stygmatyzującą. Taką modyfikacją jest asfiksjofilia, czyli upodobanie do czynności mających asocjować stymulację seksualną z niedotlenieniem mózgu.

W literaturze napotykamy także inne określenia, jak na przykład kotzwarrism i hipoksyfilia. Zawsze jednak chodzi o trawestacje standardowych, wpisanych w rutynę doznań psychofizycznych. Brak tlenu, który upośledza działanie neuronów, zarazem prowadzi do wytworzenia odmiennych stanów świadomości, będących dla jakiegoś odsetka ludzi źródłem intensywnej, niecodziennej przyjemności. Asfiksjofile odbierają część objawów hipoksji jako powiązanych z intensyfikacją doznań seksualnych, albowiem upośledzenie dopływu tlenu do mózgu może prowadzić do euforii hipoksyjnej, zaniku kontroli ego, oszołomienia, antynomicznego podniecenia wywołanego łamaniem zakazów, które mogą modyfikować i intensyfikować doznania onanistyczne i orgazmiczne. Niedotlenienie prowadzi dodatkowo do redukcji inhibicji niższych ośrodków mózgowych, w których wyzwalane są emocje seksualne. Mogą one swobodnie emanować, co w powiązaniu z zanikiem kontroli ego tworzy niespotykane połączenie.

Istnieją różne techniki doprowadzania do seksualnie gratyfikującego deficytu tlenu w organizmie. Za "klasyczne” uznawane są zaciskające się na szyi pętle, szale, ręczniki, prześcieradła itp. Sposobem działania przypominają one garotę lub stryczek ${ }^{13}$. Towarzyszą im inscenizacje przypominające egzekucję na szubienicy z wykorzystaniem techniki krótkiego spadku lub zawieszenia ${ }^{14}$. Inne, klasyfikowane jako asfiksja atypowa, to podtapianie, blokowanie dróg oddechowych

13 Asfiksja jest czynnikiem śmiertelnym (lub jednym z czynników) w przypadku garoty i powieszenia. Odgrywa też ważną rolę w uśmiercaniu z użyciem letalnej iniekcji (lethal injection). Obecnie toczy się spór o to, czy aby na pewno tego typu egzekucja jest zawsze szybka i przebiega bezboleśnie. Z założenia tak właśnie powinno być. Z badań i opisów świadków wynika jednak, że nie zawsze proces ten odbywa się tak sprawnie, jak zakłada procedura. Między innymi nieudane wkłucie (skutkujące powolnym przesączaniem trucizny przez tkanki, a nie natychmiastowym wprowadzeniem do krwioobiegu i centralnego układu nerwowego), indywidualne różnice w reakcjach na podane substancje i inne przyczyny mogą prowadzić do bolesnej i długotrwałej agonii. Zdaniem niektórych badaczy w pewnych przypadkach skazany może zachować świadomość umierania, doznawać silnego bólu i konać z powodu asfiksji powodowanej działaniem relaksanta (pancuronium) uniemożliwiającego oddychanie i poruszanie się - T.A. Zimmers et al., Lethal injection for execution: Chemical asphyxiation?, „PLoS Medicine” 4, 2007, nr 4, s. 646-653, http://journals.plos.org/ plosmedicine/article?id=10.1371/journal.pmed.0040156 (dostęp: 3.09.2017).

${ }^{14}$ Lost all hope, suicide methods, hanging, http://lostallhope.com/suicide-methods/hanging (dostęp: 4.12.2016). 
za pomocą plastykowego worka lub niedrożnej maski gazowej, upośledzanie procesu oddychania prądem elektrycznym, inhalacja toksycznych lub anestetycznych gazów oraz krępowanie ciała uniemożliwiające respirację. Według wielu naukowych źródeł asfiksjofilia, jej typowe i atypowe postacie, bywa powiązana z używaniem takich rekwizytów, jak ubranie płci przeciwnej, pornografia, wibrator czy lustra. Przynajmniej część asfiksjofili korzysta z „seks-narzędziowni”, kreuje wysoce specyficzne konstelacje bodźców i scenerie. Erotycznym i autoerotycznym zachowaniom często towarzyszy transponowanie fantazji w specyficzne rytuały. Czynności mogą być oglądane w lustrze, fotografowane, nagrywane, a współcześnie również przesyłane $\mathrm{w}$ rzeczywistym czasie za pomocą łączy internetowych. Możliwości te wytwarzają ciekawy paradoks, czynność autoerotyczna staje się społeczna i publiczna, co wraz ze staraniami umknięcia społecznej kontroli zachowań i doznań wpisuje ją w obszar zainteresowań socjologicznych.

Innym aspektem uspołecznienia i upublicznienia są działania agend formalnej kontroli społecznej. Jeśli przyjmujemy, że w zdecydowanej większości tego typu praktyk zgony są niezamierzone (nie są samobójstwami lub zabójstwami), to zarazem uznajemy je za wypadki wynikające $z$ utraty panowania nad przebiegiem sytuacji. Jednocześnie funkcjonujemy w społeczeństwach, w których ustanie życia wymaga profesjonalnego orzeczenia. Sytuacje niejednoznaczne muszą zostać rozstrzygnięte według prawnie obowiązujących procedur przez upoważnione do tego agencje. O ile śmierć jest dla denata lub denatki niekwestionowanym, ostatecznym wymknięciem się mechanizmom kontroli społecznej, o tyle zwłoki oraz scena i scenografia zgonu zostają poddane skrzętnemu, wieloaspektowemu badaniu. Wszczęte jest dochodzenie mające na celu określenie przebiegu zdarzeń, odkrywane są motywy działania (przynajmniej podejmowane są takie próby), ustalane konsekwencje dla osób żyjących. Śmierć, choć w wymiarze jednostkowym jest zdarzeniem unikatowym i zazwyczaj intymnym, w tym wypadku zostaje upubliczniona. Miejsce zdarzenia przechodzi we władanie ludzi obcych zmarłemu i jego krewnym oraz znajomym, których procedury dochodzeniowe upoważniają do bezpardonowego wejścia w prywatny, intymny świat. Nie muszą pytać o zgodę, by mieć do niego dostęp (mówiąc wprost, wolno im zaglądać do szuflad, szaf, pod dywan, do toalety, przyglądać się pościeli i prezerwatywom, jeśli takowe znajdą). Ich zadaniem staje się pieczołowite spisywane, przeglądane rekwizytów ze sceny śmierci: lin, chust, szali służących do zaciskania szyi, lateksowych masek i kombinezonów, wibratorów i lubrykantów, pobieranie śladów biologicznych itp. Zwłoki są fotografowane, ciało dokładnie badane wraz ze wszystkimi tabuizowanymi otworami. Niektórym zmarłym za życia nie przytrafiło się tak drobiazgowe badanie jak po śmierci. Protest jest niemożliwy ze strony nieżyjących i trudny dla żywych.

Uwagę śledczych zwraca także (lub szczególnie) pornografia, dość często towarzysząca autoerotycznym praktykom, którą raczej konsumuje się w prywatnym zaciszu, by wymknąc się moralizatorskim spojrzeniom i napomnieniom 
agentów kontroli społecznej. Śmierć, będąca wynikiem dewiacyjnego czynu, zrzuca także tutaj zasłonę prywatności. Śledczy mają prawo przeglądać zdjęcia z pornograficznej broszury, komputerowe kolekcje i odtwarzać zawarte tam filmy. Obecność pornografii zazwyczaj obciąża ofiarę. Szczególne zainteresowania i oceny wzbudza tak zwana ekstremalna pornografia, ukazująca przemoc, ból, zachowania zagrażające zdrowiu i życiu. Snute są przyczynowo-skutkowe domysły. Stawiane są pytania, na ile pornografia może być uznana za jeden z głównych czynników wzbudzających specyficzne, ryzykowne zachowania, na ile może być sklasyfikowana jako pośredni powód śmierci ${ }^{15}$. Wyobraźnia wypełnia niejednoznaczności. Dochodzi do swoistego odwrócenia. Zazwyczaj niepożądana w takich momentach i dotycząca takich obiektów ciekawość i zaangażowanie mają zostać rozbudzone. Ekstremalna pornografia jest często trudno dostępna nawet dla jej badaczy, a stygmat korzystających z tego typu materiałów jest na nich przenoszony; naukowo motywowane zainteresowanie zatem nie chroni przed nim ${ }^{16}$. Niebezpieczeństwo stygmatyzacji zdaje się nie stanowić zagrożenia dla osób przeprowadzających dochodzenie. Mogą korzystać z zakazanych treści w legalny sposób. By ustalić jakąś wersję prawdy, zostaje im udzielone prawo łamania tabu bez konsekwencji, jakie zazwyczaj pociągają za sobą takie sposoby działania.

\section{Paradoks drugi: (auto)erotyczne i społeczne}

Do wskazanych argumentów o społecznym charakterze asfiksjofilii dodajmy kolejne. Aspołecznej naturze przeczą także przypadki udziału partnerów. Niektóre sposoby wywołania stanu hipoksji wręcz zakładają ich obecność, na przykład szczelnie założona maska, zamknięty pochłaniacz i założenie, że proceder trwa aż do utraty przytomności. Wywołany przez niedotlenienie zespół objawów jest niebezpieczny (nie tylko dla asfiksjofilów, również dla nurków, pilotów, alpinistów; tyle że pierwsi celowo wywołują zazwyczaj niepożądane symptomy). Powód jest prosty. Wskazane zaburzenia mogą uniemożliwić uruchomienie procedury ratującej przed utratą świadomości, pozbawić kontroli nad sytuacją i doprowadzić do śmierci (niewłaściwa ocena sytuacji, zakłócenie widzenia i koordynacji ruchowej może udaremnić rozwiązanie węzła, zmniejszenie napięć czy zwolnienie

15 Tego typu spekulacje są dość skrzętnie wykorzystywane do amplifikacji działań antypornograficznych. Szczególnie napiętnowana jest ekstremalna pornografia. O ile soft porn bywa traktowana pobłażliwie, o tyle extreme porn postrzegana jest jako diabeł wcielony. Generalnie lubieżne produkcje są jednym $z$ ulubionych obszarów kontrolnych interwencji. Ich intensywność wzrasta wraz $\mathrm{z}$ indeksem określanym słowami hard i extreme.

16 S. Jones, S. Mowlabocus, Hart times and rough rides: The legal and ethical impossibilites of researching „shock” pornographies, „Sexualities” 12, 2009, nr 5, s. 613-628, https://www.academia. edu/2212589/Jones_S._and_Mowlabocus_S._2009_.Hard_Times_and_Rough_Rides_The_Legal_ and_Ethical_Impossibilities_of_Researching_Shock_Pornographies_Sexualities_12_5 (dostęp: 4.12.2016). 
pętli). Jeśli nie nastąpi dopływ tlenu, nieuchronnie dojdzie do utraty przytomności i uduszenia. Asysta partnerska radykalnie obniża ryzyko. Nieprzytomny asfiksjofil jest całkowicie zależny od działania drugiego człowieka (chyba że zaplanował użycie innej procedury ratunkowej, która może okazać się zawodna). To przykład społecznej gry opartej na ekstremalnej kontroli i całkowitym zaufaniu. Partner lub partnerka ma świadomość tego, że czyjeś życie jest zależne od tego, co zrobi lub czego nie zrobi. Świadomość posiadania władzy i realna władza nad czyimś źyciem lub śmiercią to niezwykły element, który nie pojawia się tak często (przynajmniej w takiej formie) w praktykach seksualnych ludzi ${ }^{17}$. Ten rodzaj władzy ostatecznej to dość unikalny kontekst. Granica śmierci i jej przekraczanie wzbudza zróżnicowane reakcje, począwszy od strachu i przerażenia, a skończywszy na ekscytacji i euforii. Potencjalne mordercze instynkty mogą zostać zaspokojone. Pytaniem bez odpowiedzi pozostaje, jak często wyobraźnia kusi opcją odebrania sobie życia, zamianą roli kochanka/ki w kata.

Literatura kryminologiczna opisuje przypadki śmierci podczas uprawiania seksu $\mathrm{z}$ podduszeniem ${ }^{18}$. Na ich podstawie trudno orzec, kiedy śmierć powiązana $\mathrm{z}$ opisywanymi praktykami wynikła $\mathrm{z}$ niefortunnego zbiegu okoliczności lub błędu, a kiedy była samobójstwem ${ }^{19}$ lub morderstwem. W niektórych przypadkach dochodzi do erotycznie motywowanej, celowej śmierci. Zdarzają się także przypadki synchronicznego samobójstwa tandemu uprawiającego seksualną grę. Ogólnie medycyna sądowa przyjmuje, że cechą charakterystyczną zachowań (auto)erotycznych, odróżniającą od samobójczych, jest korzystanie z różnego rodzaju systemów zabezpieczeń, mających na celu przerwanie asfiksji zanim dojdzie do trwałych uszkodzeń mózgu lub śmierci. Aczkolwiek ich wspólną cechą jest zawodność oraz to, że ich obecność ułatwia klasyfikacje i nie rozstrzyga jednoznacznie, jak rzeczywiście było.

17 Praktyki seksualne w naszej kulturze kojarzą się zazwyczaj z dawaniem życia, a nie jego zabieraniem, z Erosem, a nie z Thanatosem (choć ogląd ten zmienił się nieco wraz z pojawieniem się AIDS.) Jednak prokreację można także rozważać, patrząc z perspektywy władzy i kontroli. Wstrzemięźliwość i inne sposoby antykoncepcji dały ludziom możliwość kontroli narodzin. Przez kontrolę nad legalnością i nielegalnością sposobów i środków antykoncepcyjnych władza sięga wprost do alkowy implicite i/lub explicite. Osoby prokreujące zaś (przynajmniej te, które czynią to świadomie/refleksyjnie) korzystają z możliwości powoływania do życia, jednakże dokonując wyboru, paradoksalnie nie dysponują zgodą jego przedmiotu/podmiotu — potencjalnej, przywoływanej z niebytu osoby. Poczynają potencjalnie samoświadomą istotę, dając życie, co oznacza, że równocześnie dają cierpienie i nieuchronną śmierć. Reprodukcja życia jest zarazem reprodukcją śmierci. Prokreacja i anihilacja są jak awers i rewers, jednak w kulturze zachodniej to powiązanie stanowi zazwyczaj temat tabu.

18 L.B. Shields et al., Atypical autoerotic death, „The American Journal of Forensic Medicine and Pathology" 26, 2005, nr 1, s. 53-62.

19 Nie da się wykluczyć samobójstwa kamuflowanego asfiksjofilią. Inscenizacja może zawierać rekwizyty sugerujące dostępność procedur ratunkowych, ale nie jest to definitywny dowód pozwalający wykluczyć motywację samobójczą. 
Aby zadziałał układ asfiksyjnej gry partnerskiej, pełną kontrolę musi dopełnić pełne zaufanie. Z jednej strony potrzebna jest techniczna kontrola nad sytuacją, na przykład możliwość szybkiego usunięcia stryczka zadzierzgniętego na szyi, z drugiej zaś konieczne jest, by zaufana osoba zlikwidowała śmiertelny ucisk po utracie przytomności partnera lub partnerki inscenizacji. Jeśli zaufanie zawiedzie, wcześniejsza umowa nie będzie dotrzymana, nastąpi zgon (w wersji solo można się pokusić o poruszenie kwestii zaufania do samego siebie). Jako istotną składową asfiksjofilii (analizowanej w ramach psychopatologicznego paradygmatu) wskazuje się zaburzenia osobowościowe $\mathrm{z}$ wpisaną $\mathrm{w}$ nie tendencją do autodestrukcji (kojarzoną na przykład z osobowością pograniczną). Jeśli jednak uznać, że zaufanie do siebie i innych jest elementem zdrowia psychicznego, pokłosiem bezpiecznego przywiązania, to $\mathrm{w}$ przypadku asfiksjofilii sprzęgałoby się ono $\mathrm{z}$ autodestrukcją i poszukiwaniem doznań bólowych. A to komplikuje próby ewaluacji i kategoryzacji. Powodem jest właśnie zaufanie wskazywane jako fundamentalny element zdrowej osobowości. W tekstach z psychopatologii często prezentowany jest pogląd, że trudności osobowościowe sprzęgają się z zakłóconym procesem psychicznego przywiązywania się do matki lub jej ekwiwalentów. Jak zakłada teoria przywiązania Johna Bowlby’ego, zręby osobowości tworzą się bardzo wcześnie - w pierwszych miesiącach życia ${ }^{20}$. Okazje do wytworzenia bezpiecznego przywiązania dają szansę na rozwój zdrowej osobowości. Jeżeli trudności relacyjne doprowadzą do ambiwalentno-lękowych lub unikających zakłóceń w przywiązaniu, skutkiem mogą być zaburzenia osobowościowe o szerokim spektrum (paranoidalne, pograniczne, schizoidalne itp.). Upraszczając i konkludując zarazem, można powiedzieć, że jeśli asfiksjofil lub asfiksjofilka są w stanie zaufać drugiej osobie w tak ekstremalnej sytuacji, jak praktyka wprost zagrażająca życiu, oznacza to, że są osobami pierwotnie bezpiecznie przywiązanymi. Innymi słowy, ich zrąb osobowościowy jest solidny i zdrowy, zarazem są aktorami patologizowanej praktyki seksualnej. Paradoks stanowi wysoki poziom zaufania do innych, będący punktem wyjścia do budowania stabilnych relacji oraz zdrowia psychicznego i oddawanie się praktyce będącej zagrożeniem dla nich i fizycznego trwania. Ta kontrowersyjna konstatacja komplikuje obraz i wzbudza dysonans poznawczy, albowiem zaciera granice pomiędzy normą i dewiacją w kontekście, który jest zazwyczaj jednoznacznie patologizowany.

Aspekt społeczny tego specyficznego zachowania nie ogranicza się jedynie do swoistego wykorzystywania społecznych doświadczeń jednostek i do relacji kontrola-zaufanie. Poprzez emocjonalne angażowanie się w związki z otoczeniem ten, kto oddaje się działaniom definiowanym jako wykroczenie (odstępstwo od normy), często wikła się napięcia wyzwalane przez triadę: wstyd, poczucie winy i wyrzuty sumienia. Oddziałują one na więzi, ujawniając zarazem swój

20 J. Bowlby, Attachment and Loss, t. 1. Attachment, Aylesbury 1971; t. 3. Loss, Harmondsworth 1991. 
społeczno-kontrolny potencjał. Emocje, takie jak wstyd i poczucie winy są lękami przed deprecjacją i degradacją, przed tym, co zdarzy się, kiedy zostaną ujawnione nienormatywne działania. Poczucie winy jest lękiem wywołanym nieodpowiadaniem myśli i czynów jednostki normatywnym oczekiwaniom otoczenia. Wstyd jest emocją pojawiającą się w wyniku braku koherencji pomiędzy wyobrażeniami o sobie (dzięki którym jednostka podtrzymuje spójność biograficzną) i rzeczywistymi zachowaniami, jest konsekwencją rozdźwięku między "ja” idealnym i „ja” realnym ${ }^{21}$. Patrzymy więc za każdym razem na siebie oczyma innych. Nie dziwi więc, że odczucia te pojawiają się, gdy ktoś nie potrafi powstrzymać się przed czynnościami definiowanymi przez otoczenie społeczne jako nieodpowiednie i karygodne. Nie zaskakuje odczuwanie ich jako przykrych i wpływających negatywnie na samoocenę. Klasyfikacja i walencja nienormatywnego zachowania seksualnego są osadzone w ocenie społecznej. W przypadku świadomości praktykowania parafilii (zachowań skategoryzowanych jako dewiacyjne) indukowanie przykrych reakcji jest ważne, gdyż dotyczy dwóch istotnych kwestii, dwóch sposobów powiązania wewnętrznego świata jednostki i świata społecznego: tożsamości i zaufania. Jednostce jest trudno utrzymać określone, przychylne narracje o sobie, pozytywną samoocenę i szacunek do siebie, innym będzie trudno utrzymać zaufanie, kiedy odkryją, że mieli mylne mniemanie o niej, że zawiodła ich oczekiwania. Emocje te potrafią więc silnie modyfikować zachowania, jednakże nie zawsze ich kontrola jest równa powstrzymaniu się od jakiegoś działania.

\section{Nienormatywność praktyk}

Zachowania asfiksyjne są słabo zbadane i chętnie patologizowane. Podkreślanie nienormatywności ułatwiają przypadki śmierci, przy których badaniu zostają ujawnione fakty wskazujące na współobecność i powiązanie $z$ masochizmem, transwestytyzmem, klizmafilią czy pigmalionizmem oraz z zaburzeniami takimi, jak depresja czy patologiczna osobowość. A jednym z powodów asocjowania jest uznanie praktyk asfiksyjnych za formę samouszkodzenia, autoagresji, autodestrukcji (aczkolwiek jest to dyskusyjna interpretacja, gdyż zazwyczaj uszkodzenie ciała i śmierć nie są celem; jednocześnie niedotlenienie prowadzi zawsze do śmierci pewnej ilości komórek nerwowych, choć jest to efekt uboczny i niepożądany). Niekiedy, podobnie jak w wypadku pozostałych parafilii, zachowania tego typu są wprost kategoryzowane jako dewiacja czy patologia. Patologizacje asfiksjofilii często uwypuklają wątek przymusu wewnętrznego. Osoba wyzbywa się

21 N. Elias, O procesie cywilizacji. Analizy socjo- i psychogenetyczne, przeł. T. Zabłudowski, K. Markiewicz, Warszawa 2011, s. 495-511; A. Giddens, Nowoczesność i tożsamość. „Ja” i społeczeństwo w epoce późnej nowoczesności, przeł. A. Szulżycka, Warszawa 2002, s. 51-59; G. Simmel, Przyczynek do psychologii wstydu, [w:] idem, Pisma socjologiczne, przeł. M. Łukasiewicz, Warszawa 2008, s. 164-173. 
samokontroli, kontroli będącej ekstensją , ja", i jest kontrolowana przez wewnętrzne mentalne dynamiki, trudne do umiejscowienia i mające cechy kompulsji nie można im się oprzeć wysiłkiem woli. Mechanizm jest trudny do uchwycenia i zrozumienia. W psychologii funkcjonuje podział na zachowania egosyntoniczne i egodystoniczne. Pierwsze to te, w których nie ma rozdźwięku pomiędzy określonymi aspektami „ja”, w przeciwieństwie do drugich, w których on występuje. W uproszczeniu - jeśli chcę coś zrobić, robię to i dobrze się z tym czuję, jest to ilustracja zachowania egosyntonicznego. Jeśli nie chcę i źle się z tym czuję, ale robię to wbrew sobie, jest to działanie egodystoniczne. Zachowania obsesyjno-kompulsywne da się wpisać zarówno w jedną, jak i w drugą kategorię. Mogą być subiektywnie odbierane jako syntoniczne: ktoś może pozytywnie odnosić się do własnego perfekcjonizmu i kontroli przybierającej postać potrzeby porząaku, czyszczenia, sprzątania. Bywają jednak także źródłem udręki: ktoś może nienawidzić tego, że nie potrafi pójść spać, jeśli najpierw nie pozmywa lub wyjechać na wakacje zanim nie odkurzy mieszkania i nie umyje okien.

Część badaczy zajmujących się zjawiskiem prezentuje pogląd, że istnieje profil psychologiczny asfiksjofila, będący korelacją patologicznych dynamik. Ich zdaniem przeciętny osobnik praktykujący tę formę zachowań seksualnych to adolescent lub młody mężczyzna. Powołują się na stwierdzenia psychologów, z których wynika, że przyczyn praktyk należy doszukiwać się między innymi w molestowaniu seksualnym i fizycznym (przyjmującym postać duszenia). Wskazują na powiązania $\mathrm{z}$ masochizmem i innymi zaburzeniami ${ }^{22}$. W przypadku asfiksjofilii próba tworzenia profilu budzi wątpliwości. $Z$ wielu źródeł wynika, że zróżnicowanie wśród praktykujących jest bardzo duże $\mathrm{e}^{23}$. Zredukowanie różnorodności do ujednoliconego profilu jest obarczone znacznym błędem. Wydaje się, że nie istnieje jednorodny, patologiczny model, ale funkcjonuje stereotypowa percepcja społeczna. Tworzenie profili jest raczej kolejnym mechanizmem patologizowania praktyki i sprawowania kontroli na wizerunkiem osób zaspokajających nienormatywnie potrzeby seksualne. Nawet w kwestii cechy takiej, jak płeć apeluje się o rozwagę. Przyczyną jest podstawa wnioskowania. Według niektórych autorów $\mathrm{z}$ ostrożnością należy podchodzić do statystyk informujących o tym, że autoerotyczna asfiksja jest przyczyną zgonów głównie mężczyzn, a co za tym idzie - jest ona przede wszystkim przez nich praktykowana. Brent Turvey twierdzi, że fakt ten wynika ze sposobu prowadzenia dochodzenia. W przypadku kobiet

22 Zob. A.P. Jenkins, When self-pleasuring becomes self-destruction: Autoerotic asphyxiation, artykuł zaprezentowany na The Annual Meeting of the American Alliance for Health, Physical Education, Recreation and Dance, Orlando 2000.

${ }^{23}$ Zob. A. Ameller et al., op. cit.; R.W. Byard, Autoerotic death - characteristicfeatures and diagnostic diffictulties, „Journal of Clinical Forensic Medicine” 38, 1994 , nr 4 ; A.P. Jenkins, op. cit.; D. Martz, Behavioral treatment for a female engaging in autoerotic asphyxiation, „Clinical Case Studies” 2, 2003, $\mathrm{nr} 3$; B.E. Turvey, An objective overview of autoerotic fatalities, http://www.selfbound.net/tech/autoerotic_fatalities.html (dostęp: 5.04.2017). 
patolodzy i śledczy analizują sytuację, pozostając pod wpływem uprzedzenia (zakładają, że kobiety nie praktykują asfiksji) i nie klasyfikują śmiertelnych przypadków jako wynikających z analizowanego sposobu osiągania satysfakcji seksualnej. Za błędnymi interpretacjami zatem stałoby przekonanie, że kobiety „tego nie robią. Turvey zaprezentował w artykule przypadki wskazujące na błędne zakwalifikowanie w policyjnych statystykach zdarzeń, których przyczyną była płeć denata. Podaje także w wątpliwość często obecne w literaturze wskazanie, że asfiksjofilia jest silnie powiązana $z$ transwestytyzmem ${ }^{24}$. Kobiety posługują się zazwyczaj innymi sposobami wywoływania niedotlenienia niż mężczyźni. $Z$ analizy dostępnych materiałów wynika, że wykorzystane środki są „skromniejsze i prostsze”. Rzadziej posługują się rekwizytami i tworzą inscenizacje, a te odwołują się do innych treści (np. „dziewczyna z haremu”). Wreszcie zdaje się, że ich praktyki mają rzadziej charakter samotniczy ${ }^{25}$. Byłby to kolejny powód prawdopodobieństwa niedoszacowania liczby kobiet praktykujących asfiksjofilię ${ }^{26}$.

24 B.E. Turvey, op. cit.; por. także N. Behrendt, N. Buhl, S. Seidl, The lethal paraphiliac syndrome: accidental autoerotic deaths in four women and a review of the literature, "The International Journal of Legal Medicine" 116, 2002, s. 148-152, https://www.researchgate.net/publication/11267860_ The_lethal_paraphiliac_syndrome_Accidental_autoerotic_deaths_in_four_women_and_a_review_of_the_literature (dostęp: 5.11.2016).

${ }^{25}$ Jednakże może to być artefakt wynikający z tego, że w literaturze dostępne są opisy kobiet, które zostały uduszone podczas uprawiania seksu z partnerem. Na przykład L.B.E. Shields et al. (op. cit.) opisali przypadek dwudziestodwuletniej kobiety, która prosiła partnera, by podczas stosunku zaciskał jej na szyi pętlę zrobioną z prześcieradła. Ta praktyka często towarzyszyła ich kontaktom seksualnym. Przypadek ten jest ciekawy z kilku wspomnianych względów. Dotyczy asfiksjofilki, a według statystyk kobiety rzadko korzystają $\mathrm{z}$ takich praktyk. Podduszenie nie miało charakteru autoerotycznego. Wreszcie ilustruje fakt, że obecność drugiej osoby nie jest gwarancją przeżycia. Magdalena Okłota i współautorzy (Zgony w przebiegu asfiksji wywołanej w celu eskalacji doznań seksualnych. Opisy przypadków, „Archiwum Medycyny Sądowej i Kryminologii” 60, 2010, s. 275-280) przedstawiają przypadek śmierci kobiety spowodowanej uduszeniem przez partnera podczas stosunku płciowego, który przeczy kolejnym stereotypom związanym z żeńską hipoksyfilią. Kobieta praktykowała asfiksję w relacjach z partnerami, zachęcała ich do tego typu praktyk, będących dla niej koniecznymi do szczytowania. Na jej komputerze znajdowały się materiały homo-, hetero- i autoerotyczne. Pornografia przedstawiała analizowane praktyki i była wykorzystywana między innymi w celu przysposabiania partnerów do preferowanych przez kobietę sposobów współżycia. W kontrze do przytoczonych opisów pozostaje studium przypadku (D. Martz, op. cit.) dwudziestodwuletniej kobiety, która w procesie terapeutycznym rozwinęła wątek asfiksyjny. W okresie adolescencji onanizowała się regularnie, zazwyczaj raz w tygodniu, ale do orgazmu potrzebna jej była hipoksja osiągana za pomocą samodzielnego podduszenia się. Procederowi towarzyszyła powtarzająca się fantazja, w której była wiązana przez bliżej nieokreślonego mężczyznę, zakładającego jej następnie pętlę na szyję, przerzucającego linę przez belkę, po czym naprężającego ją i wieszającego jej ciało. Orgazm wywoływany onanizmem wspomaganym hipoksją osiągany był w momencie, gdy w fantazji kobieta zawisała jak na szubienicy.

${ }^{26}$ R.W. Byard, S.J. Hucker, R.R. Hazelwood, Fatal and near - fatal autoerotic asphyxial episodes in women. Characteristic features based on a review of nine cases, „The American Journal of Forensic Medicine and Pathology" 14 1993, nr 1, s. 70-73, https://www.researchgate.net/publication/14705291 
Ogólnie trudno oszacować liczbę osób korzystających z niedotlenienia jako specyficznego „intensyfikatora” seksualnego i czyniących to w opisywany sposób. Pośrednim i nieprecyzyjnym wskaźnikiem jest niezamierzona (jak się przyjmuje) śmierć wynikająca z nieudanej praktyki. Jako takie corocznie kwalifikuje się od 500 do 1000 zdarzeń w Stanach i Kanadzie. W Niemczech statystyki zasila od 40 do 50 podobnych wypadków ${ }^{27}$. Proporcja mężczyzn do kobiet w przypadku autoerotycznej asfiksji jest oceniana jako 50 do $1^{28}$. Jednak jest to bardzo zawodna podstawa aproksymacji populacji asfiksjofili regularnie lub sporadycznie zaspokajających swoje potrzeby. Niemożność ustalenia skali zjawiska jest konsekwencją działania mechanizmów kontroli społecznej, a dokładnie nieujawniania preferencji (przez żadną ze stron) w obawie przed stygmatyzacją i tym wszystkim, co za sobą pociąga. Innym powodem są próby kontroli informacji. Utrata życia w taki sposób jest zazwyczaj trudna do zrozumienia i zaakceptowania przez bliskich i rodzinę. Samobójczy zgon jest już często zdarzeniem wstydliwym, dlatego może zostać zafałszowany. A tym bardziej zdaje się to dotyczyć śmiertelnych wydarzeń sprowokowanych asfiksją. Otoczenie stara się tak skontrolować elementy wskazujące na sposób utraty życia, by zostały temu przypisane przyczyny inne niż seksualne i/lub samobójstwo. Zdarza się, że rekwizyty są usuwane ze sceny śmierci, przearanżowane tak, by uniemożliwić ujawnienie rzeczywistego motywu zachowania. Na pośrednie i bezpośrednie sposoby patologizowania asfiksjofilii należałoby więc patrzeć jak na kolejny wymiar społecznej kontroli seksualnych praktyk.

Można postawić pytanie, dlaczego ludzie podejmują nienormatywną i ryzykowną aktywność seksualną? Ryzyko w tym kontekście jest dość duże i zróżnicowane. Jeśli najbliższe otoczenie dowie się, że ktoś praktykuje hipoksję, szczególnie motywowaną seksualnie, może to doprowadzić do dyskredytacji i stygmatyzacji. Chęć wprowadzenia takich praktyk do relacji partnerskiej może nią zachwiać. Błędy w realizacji mogą okazać się niebezpieczne dla zdrowia i życia. Andres Jenkins wskazuje kilka możliwych odpowiedzi. Zachętą mogą być: doznanie dreszczu emocji, potrzeba eksperymentowania, tendencje sadomasochistyczne, chęć realizacji tanatologicznych fantazji czy wreszcie igranie z kontrolą nad własnym i cudzym życiem ${ }^{29}$. Dreszcz emocji bardzo rzadko pojawia się w czynnościach rutynowych. Innowacje mogą go dostarczyć. Kierując się tą wskazówką,

\footnotetext{
_Fatal_and_near-fatal_autoerotic_asphyxial_episodes_in_women_Characteristic_features_based_ on_a_review_of_nine_cases (dostęp: 12.02.2017).

27 M.E.S. Modelli et al., Self-induced fatal air embolism: Autoerotic death or suicide, „Journal of Forensic Sciences" 58, 2012, nr 1.

28 D.A. Hawley, Forensic Medical Findings in Fatal and Non-fatal Intimate Partner Strangulation, Department of Pathology and Laboratory Medicine Indiana University School of Medicine, 2012, s. 11, http://dhss.alaska.gov/ocs/Documents/childrensjustice/strangulation/16.\%20Forensic\%20Medical \%20Findings\%20in\%20Fatal\%20and\%20Non-Fatal\%20Intimate\%20Partner\%20Stran-gulation\%20 Assaults\%20-\%20Hawley\%20-\%202012.pdf (dostęp: 12.09.2016).

29 A.P. Jenkins, op. cit.
} 
można wskazać różne praktyki wpływające na wzrost poziomu adrenaliny w organizmie. Jedni uprawiają seks w miejscach publicznych lub półpublicznych, inni mnożą liczbę partnerów lub ryzykują, nie używając środków ochronno-antykoncepcyjnych. Pragnienie doznawania silnych emocji jest istotnym elementem sportów ekstremalnych. Można zaryzykować stwierdzenie, że praktyki asfiksyjne graniczą ze sportami ekstremalnymi, w których ryzyko uszkodzenia ciała i śmierci jest także wysokie. Różni je poziom akceptacji społecznej. Tendencje sadomasochistyczne zdają się dość ściśle związane z asfiksjofilią, zarówno za sprawą igrania z bólem, jak i totalnej kontroli. Asfiksjofilia jest w pewnym stopniu immanentnie masochistyczna, przynajmniej w tych przypadkach, gdy w nieunikniony sposób towarzyszy jej ból. Jego precyzyjne dozowanie jest kluczowym elementem gry. Ilustracją tego jest powszechne używanie materiałów, które redukują ból i uszkodzenia w przypadku stosowania różnorodnych pętli zaciskanych na szyi. Jeśli ktoś wiesza się lub jest wieszany przez inną osobę $\mathrm{w}$ celach erotycznych, to stryczek jest zazwyczaj owinięty miękkim, redukującym tarcie i inne bolesne bodźce materiałem (niepozostawiane albo mniej widoczne są też ślady mogące wzbudzić niepożądaną ciekawość innych osób). Dzięki takim modyfikacjom można zawisnąć, ale poziom bólu nie jest tak wysoki, jak w przypadku zastosowania szorstkiego, twardego konopnego sznura czy liny $\mathrm{z}$ tworzywa syntetycznego ${ }^{30}$.

Innym podobieństwem zdaje się pozostawanie w epicentrum wymian władzy w seksualnym kontekście. Kluczowe jest kontrolowanie bezpieczeństwa, a jego podstawą jest wrażliwość na to, czego doświadcza partnerka lub partner. Po epizodzie intensywnej sadomasochistycznej gry często następuje faza „opieki po" „kat” przeistacza się w „opiekuna”, co stwarza warunki do psychicznego, emocjonalnego zbliżenia między uczestnikami. Innymi słowy, tego typu praktyki mogą wytworzyć intymność nacechowaną poziomem zaufania trudnym do osiągnięcia w „zwyczajnym” związku ${ }^{31}$. Tanatologiczne fantazje zdają się towarzyszyć opisywanym praktykom w pewnej liczbie przypadków. Za ich wskaźnik zostają uznane zarówno elementy inscenizacji, jak i treści odnajdywane w używanych przy takich okazjach materiałach pornograficznych. Nawiązują one między innymi do fotografii i filmów klasyfikowanych jako ekstremalne ze względu na obrazowanie śmierci, egzekucji, torturowania, dekompozycji ciała itp. Inscenizacje również

${ }^{30}$ R.W. Byard, op. cit.

31 Takie ustalenia depatologizują nienormatywne praktyki seksualne. Zdejmujący odium opis BDSM można znaleźć w artykule D.J. Williamsa Different (painful!) strokes for different folks: A general overview of sexual sadomasochism (SM) and its diversity, „Sexual Addiction \& Compulsivity” 13, 2006, https://www.researchgate.net/publication/233686844_Different_PainfulA_Strokes_for_Different_Folks_A_General_Overview_of_Sexual_Sadomasochism_SM_and_its_Diversity (dostęp: 12.09.2016). Autor wskazuje, że gry tego typu często uprawiają w Stanach Zjednoczonych ludzie wykształceni, dobrze zarabiający, kreatywni seksualnie, posiadający dystynktywną tożsamość i przystosowani społecznie, co nie przekłada się na stereotyp sugerujący problemy emocjonalne, niską samoocenę, poczucie winy i potrzebę destruktywnego samookaleczania. 
imitują egzekucje. Zarówno w przypadku rzeczywistego wykonywania wyroku śmierci, jak i w asfiksjofilskiej imitacji proces jest precyzyjnie zaprogramowany, a jedną z najistotniejszych kwestii jest postępowanie zgodne ze scenariuszem (innymi słowy, działania nie są improwizowane).

\section{Zakończenie}

Praktyki asfiksyjne można uznać za precyzyjnie kontrolowane igranie ze śmiercią. Asfiksjofil bądź asfiksjofilka powtarzają preludium śmierci, doprowadzając do znacznego niedotlenienia, a nawet utraty świadomości, która potencjalnie jest prolegomeną zgonu. Można zadać pytanie, czy rzeczywiściekontrolowana utrata świadomości ma tak wyjątkowy status? Odpowiedź nie jest jednoznaczna. Zredukowanie lub wstrzymanie dopływu tlenu bardzo szybko prowadzi do niebezpiecznych zakłóceń w funkcjach mentalnych. Istnieją jednak fizjologiczne, cykliczne, normalne dla naszego gatunku, radykalne zmiany stanu psychicznego. $\mathrm{Z}$ reguły codziennie zapadamy w sen, który oznacza utratę świadomości i samoświadomości. Zazwyczaj jest to przyjemny moment, oczekiwany, rytualizowany, a nawet celebrowany. Nigdy nie ma pewności, że będzie nam dane obudzić się i powrócić do stanu czuwania i samoświadomości. W pewnym sensie co noc ćwiczymy umieranie, ale rzadko kiedy myślimy taką kategorią, zapadając w sen. A przecież mówi się, że śmierć jest wiecznym snem bez śnienia i przebudzenia. Zasypianie nie dla wszystkich oznacza jednak oczekiwane i przyjemne zmiany mentalne. Somnifobia (zwana też hipnofobią), czyli paniczny strach przed zaśnięciem, to zaburzenie redefiniujące zasypianie. Strach przed zaśnięciem może wiązać się z lękiem przed śmiercią we śnie (tanatofobia). Istnienie tego typu fobii uświadamia, że sen nie zawsze jest mile oczekiwanym stanem, odpoczynkiem, regeneracją. Antycypacja snu bywa asocjowana $\mathrm{z}$ antycypacją śmierci. Celowa asfiksja jest otwieraniem i zamykaniem „wrót na tamtą stronę”. Towarzyszące jej objawy da się łączyć z satysfakcją seksualną, ale proceder wzbudza także refleksje tanatologiczne i eschatologiczne. Asfiksję można postrzegać jako symboliczne i fizyczne zbliżenie do ostateczności. Każda tego typu sesja jest stanem pogranicznym, dzieje się na progu nieodwracalnej transgresji. Nie można orzec jednoznacznie (gdyż indywidualne różnice są zbyt duże), ale można założyć, że proporcje między gratyfikacją seksualną a „tanatologiczną” są zmienne i dla części osób erotyka jest pretekstem do zaaranżowania „randki z ostatecznością”. Igranie ze śmiercią za sprawą asfiksji bywa akcentowane specyficznymi inscenizacjami. Jedną z nich jest egzekucja przez powieszenie. Gdy „egzekucja” odbywa się przy współudziale partnera lub partnerki, uczestnicy wchodzą w rolę skazańca i kata.

Jeśli wrócić raz jeszcze do pytania o asfiksyjną motywację, można pokusić się o pójście następującym tokiem rozumowania. Żyjemy w hedonistycznej kulturze kolekcjonowania intensywnych wrażeń, hołubiącej młodość, sprawność i inten- 
sywne istnienie, zarazem niechętnej śmierci, skłonnej do jej negacji, a co najmniej odraczania i marginalizacji. Unikamy oswajania się z agonią, niebytem. Nieoswojona, nieobecna w codzienności lub odrealniona, zapośredniczona za sprawą medialnego przekazu śmierć albo zdaje się nie istnieć, albo wzbudza bardziej intensywny niż u minionych pokoleń strach. Asfiksjofilia asocjuje ekscytację, niezwykłe doznania pograniczne z ryzykiem śmierci i powtarzaniem jej wstępnej fazy, naznaczonej zakłóceniami świadomości, jej utratą. Być może, poza powiązaniem z seksualnym pobudzeniem i zaspokojeniem, jest okazją do oswojenia się ze strachem przed zejściem w niebyt. Być może dzięki jej praktykowaniu dochodzi do redukcji strachu przed zgonem, a w pewnym momencie do aranżacji własnej śmierci zsynchronizowanej z seksualnym wzlotem. Skojarzenie wygasania świadomości, traktowanego jako preludium śmierci, z ekscytacją i powtarzanie owej asocjacji z czasem może redukować lęk na rzecz ekscytującej erotyzacji.

Jednocześnie kultura zachodnia należy do słabo zainteresowanych wykorzystaniem odmiennych stanów świadomości i ich bezpiecznym, kontrolowanym wzbudzaniem, których celem jest próba poszerzenia samoświadomości czy wejścia na inną ścieżkę rozwoju. Nie wypracowuje i nie używa się w takim celu technik oddechowych (przyspieszanie i pogłębianie lub spowalnianie, spłycanie i wstrzymywanie) i potencjału zawartego w seksualności. W tym względzie jesteśmy raczej importerami, a nie eksporterami - w sensie przejmowania $\mathrm{z}$ innych kultur specyficznych praktyk i ich implementowania. Przyswajanie obcych osiągnięć kulturowych nie oznacza, jak to zazwyczaj bywa, całkowitego braku własnych dokonań. Christina i Stanislav Grof wypracowali technikę terapeutyczną, którą nazwali holotropową pracą oddechem. Termin „holotropowy” rozumieją jako "dążący ku całości”. Celem terapii jest wykorzystanie odmiennych stanów świadomości do poszerzenia i uwrażliwienia funkcjonowania $\mathrm{w}$ codzienności. Są one osiągane za pomocą modyfikacji oddechu, relaksacji wspomaganej muzyką i ekspresji z użyciem rysunków. Podstawą uzyskiwanych stanów świadomości są mechanizmy fizjologiczne wywołane specyficznymi modyfikacjami oddychania. Procesy te są skomplikowane, jednak skrajnie upraszczając, wskażmy, że przyspieszony oddech ma zapewnić skuteczne usuwanie dwutlenku węgla z organizmu. Kora mózgowa, jako najmłodsza struktura mózgu, jest najbardziej wrażliwa na fizjologiczne wyzwania, począwszy na deprywacji tlenu, a skończywszy na intoksykacji alkoholowej. Zdaniem Grofów podczas oddychania holotropowego działanie kory mózgowej ulega inhibicji, a archaiczne struktury mózgu są poddane aktywacji, a wraz z nimi procesy podświadome ${ }^{32}$.

Asfiksja zajmuje skrajną pozycję wśród celowych manipulacji respiracją, skutkuje stanem graniczącym z utratą przytomności, z bliskością śmierci. Takie sytuacje można $\mathrm{z}$ jednej strony wpisać $\mathrm{w}$ obszar groźnych patologii, $\mathrm{z}$ drugiej zaś

32 S. Grof, Holotropic breathwork: New perspective in psychotherapy and self-exploration, http:// wisdomuniversity.org/grof/module/week3/pdf/Holotropic\%20Breathwork.pdf (dostęp: 12.09.2016). 
w pogranicze psychologii transpersonalnej, która z pomocą technik oddechowych wprowadza w stan odmiennej świadomości i otwiera dostęp do funkcji mentalnych niedostępnych w stanie „zwyczajnego” czuwania. Paradoksalnie kontrola oddechu lub wręcz jego monitorowane zatrzymanie daje szansę na uwolnienie się spod kontroli kory mózgowej i potencjalne „wyzwolenie” dzięki odhamowaniu starego mózgu i jego archaicznych zapisów. W takiej perspektywie hipoksja jawi się jako potencjalne otwarcie na doświadczenia transgresyjne, archetypowe, mistyczne i wiele innych. Traci zatem wiele ze swojego statusu patologicznego, a zyskuje aspekty metafizyczne i egzystencjalne ${ }^{33}$.

\section{Bibliografia}

Ameller A. et al., Addiction to autoerotic asphyxia: A case-report, „Substance Abuse Alcohol” 4 (2), 2016, https://www.jscimedcentral.com/SubstanceAbuse/substanceabuse-4-1048.pdf.

Becker H.S., Outsiderzy. Studia z socjologii dewiacji, przeł. O. Siara, Warszawa 2009.

Behrendt N., Buhl N., Seidl S., The lethal paraphiliac syndrome: accidental autoerotic deaths in four women and a review of the literature, „The International Journal of Legal Medicine” 116, 2002, https://www.researchgate.net/publication/11267860_The_lethal_paraphiliac_syndrome_Accidental_autoerotic_deaths_in_four_women_and_a_review_of_the_literature.

Bowlby J., Attachment and Loss, t. 1. Attachment, Aylesbury 1971.

Bowlby J., Attachment and Loss, t. 3. Loss, Harmondsworth 1991.

Byard R.W., Autoerotic death - characteristic features and diagnostic diffictulties, „Journal of Clinical Forensic Medicine" 38, 1994, nr 4.

Byard R.W., Hucker S.J., Hazelwood R.R., Fatal and near - fatal autoerotic asphyxial episodes in women. Characteristic features based on a review of nine cases, „The American Journal of Forensic Medicine and Pathology" 14, 1993, nr 1, https://www.researchgate.net/publication/14705291_Fatal_and_ near-fatal_autoerotic_asphyxial_episodes_in_women_Characteristic_features_based_on_a_review_of_nine_cases.

Douglas M., Jak myśla instytucje, przeł. O. Siara, Warszawa 2011.

Elias N., O procesie cywilizacji. Analizy socjo- i psychogenetyczne, przeł. T. Zabłudowski, K. Markiewicz, Warszawa 2011.

Elias N., Społeczeństwo jednostek, przeł. J. Stawiński, Warszawa 2008.

G. A. S. P., games adolescent shouldn't play, http://www.gaspinfo.com/en/choking.html.

Giddens A., Nowoczesność i tożsamość. „Ja” i społeczeństwo w epoce późnej nowoczesności, przeł. A. Szulżycka, Warszawa 2002.

Grof S., Holotropic breathwork: New perspective in psychotherapy and self-exploration, http://wisdomuniversity.org/grof/module/week3/pdf/Holotropic\%20Breathwork.pdf.

Hawley D.A., Forensic Medical Findings in Fatal and Non-fatal Intimate Partner Strangulation, Department of Pathology and Laboratory Medicine Indiana University School of Medicine, 2012, http://dhss.alaska.gov/ocs/Documents/childrensjustice/strangulation/16.\%20Forensic\%20

33 Aspekty egzystencjalne rozumiane są tutaj w sposób zaczerpnięty z psychologii egzystencjalnej, w ujęciu takich autorów, jak m.in. Rollo May ( $O$ istocie człowieka: szkice z psychologii egzystencjalnej, przekł. M. Moryń, Z. Wiese, Poznań 1996), Abraham Maslow (Motywacja i osobowość, przeł. J. Radzicki, Warszawa 2006) czy Carl Ransom Rogers (O stawaniu się soba, przeł. M. Karpiński, Poznań 2002). 
Medical\%20Findings\%20in\%20Fatal\%20and\%20Non-Fatal\%20Intimate\%20Partner\%20Strangulation\%20Assaults\%20-\%20Hawley\%20-\%202012.pdf.

Jenkins A.P., When self-pleasuring becomes self-destruction: Autoerotic asphixation, The Annual Meeting of the American Alliance for Health, Physical Education, Recreation and Dance, Orlando 2000.

Jones S., Mowlabocus S., Hart times and rough rides: The legal and ethical impossibilites of researching „shock” pornographies, „Sexualities” 12, 2009, nr 5, https://www.academia.edu/2212589/ Jones_S._and_Mowlabocus_S._2009_._Hard_Times_and_Rough_Rides_The_Legal_and_Ethical_Impossibilities_of_Researching_Shock_Pornographies_Sexualities_12_5.

Kaufmann J.-C., Ego. Socjologia jednostki, przeł. K. Wakar, Warszawa 2004.

Laqueur T.W., Samotny seks. Kulturowa historia masturbacji, Kraków 2006.

Linkletter M., Gordon K., Dooley J., The choking game and YouTube: A dangerous combination, „Clinical Pediatrics" 49, 2010, nr 3, http://journals.sagepub.com/doi/abs/10.1177/0009922809339203.

Loss all hope, suicide methods, hanging, http://lostallhope.com/suicide-methods/hanging.

Martz D., Behavioral treatment for a female engaging in autoerotic asphyxiation, „Clinical Case Studies" 2, 2003, nr 3.

Maslow A., Motywacja i osobowość, przeł. J. Radzicki, Warszawa 2006.

May R., O istocie człowieka: szkice z psychologii egzystencjalnej, przeł. M. Moryń, Z. Wiese, Poznań 1996.

Modelli M.E.S. et al., Self-induced fatal air embolism: Autoerotic death or suicide, „Journal of Forensic Sciences" 58, 2012, nr 1.

Okłota M. et al., Zgony w przebiegu asfiksji wywołanej w celu eskalacji doznań seksualnych. Opisy przypadków, „Archiwum Medycyny Sądowej i Kryminologii” 60, 2010.

Rogers C.R., O stawaniu się sobą, przeł. M. Karpiński, Poznań 2002.

Shields L.B.E. et al., Atypical autoerotic death, „The American Journal of Forensic Medicine and Pathology" 26, 2005, nr 1.

Siemaszko A., Granice tolerancji. O teoriach zachowań dewiacyjnych, Warszawa 1993.

Simmel G., Przyczynek do psychologii wstydu, [w:] idem, Pisma socjologiczne, przeł. M. Łukasiewicz, Warszawa 2008.

The fainting game, http://www.allabo-uthaeven.org/overload/40/07/the-fainting-game. Turvey B.E., An objective overview of autoerotic fatalities, http://www.selfbound.net/tech/autoerotic_fatalities. html.

Westerman R.A., Hypoxia familiarization training by the reduced oxygen breathing method aviation medicine, „ADF Health” 5, 2004.

Williams D.J., Different (painful!) strokes for different folks: A general overview of sexual sadomasochism (SM) and its diversity, „Sexual Addiction \& Compulsivity” 13, 2006, https://www.researchgate.net/publication/233686844_Different_PainfulA_Strokes_for_Different_Folks_A_ General_Overview_of_Sexual_Sadomasochism_SM_and_its_Diversity.

Zimmers T.A. et al., Lethal injection for execution: Chemical asphyxiation?, „PLoS Medicine” 4, 2007, nr 4, http://journals.plos.org/plosmedicine/article?id=10.1371/journal.pmed.0040156.

11 Year Old Boy Dies While Playing „Choking Game”, https://www.youtube.com/watch?v+jlj-lunxLbQI. 


\section{Asphyxiophilia and control. Nonnormative practice in the socio-cultural perspective}

\section{Summary}

Asphyxiaphilia means predilection for sexual practices, which include asphyxia as key component. There are many ways to restrict the oxygen intake of living human, the most typical is choking or hanging by the neck. Paradoxically, physiological disturbance, associated usually with it undesirable symptoms caused by oxygen deficit are used by asphyxiaphilics as intense, highly gratifying sexual stimuli. These types of behavior are risky, transgressive and usually stigmatized. This are some of the reasons why they are perceived as dangerous not only physically, but socially to and why they can easily trigger variety of controlling interventions. It is interesting that on the one hand asphyxiaphilic activity often turn to be precisely planned and controlled rituals, and the loss of control can result literary in death. On the other hand, disclosure or accidental release, leak of information into communal, public environment may lead to "social death". Sociologists researching this domain encounter puzzling challenges and intriguing questions about boundaries between social and public, normative and non-normative, destructive and gratifying, compulsive and voluntary, transgressive and existential. 